Influence of Tempering and Cryogenic Treatment on Retained Austenite and Residual Stresses in Carbonitrided 18CrNiMo7-6 Low Alloy Steel

Vol. 38(1), pp. 83-96, June 2019

ISSN 1821-536X (print)

ISSN 2619-8789 (electronic)
Tanzania Journal of Engineering and Technology

Copyright (C) 2019 College of Engineering and

Technology, University of Dar es Salaam

Full Length Research Paper

\title{
Development of Improved Characteristic Equations for Lake Rukwa in Tanzania
}

\author{
Patrick C. Valimba \\ Department of Water Resources Engineering, University of Dar es Salaam, P.O. Box 35131, Dar es \\ Salaam, Tanzania. \\ E-mail:pvalimba@yahoo.com,pvalimba@hotmail.com
}

\begin{abstract}
Often Lake Rukwa characteristics have been misreported in literature giving different volumes and surface areas at similar water surface elevations. This study aimed at establishing reliable lake characteristics elevation-area-storage equations for Lake Rukwa by utilising all available data and information to define the bathymetry and derive characteristic equations. A procedure was developed that combines historical lake extents, spot heights from topographical maps and surveyed lake bathymetry to define refined bathymetry to levels it has never reached. It combined spot heights around the lake and selected 13,934 surveyed points (from 107,938 available) within the lake confined by the $820 \mathrm{~m}$ land contour boundary and define topographical raster image, which was used to extract lake volumes and surface areas between the lowest point $(778 \mathrm{~m})$ and $820 \mathrm{~m}$ boundary. Change-point analysis was used to detect segmentation of the elevation-area and elevation-volume relationships, which were fitted to a shifted power model. Contours generated from a refined bathymetry raster indicated Lake Rukwa to comprise two north and south lake basins, which are separated by a ridge lying at an altitude of $794.3 \mathrm{~m}$. The north and south lakes consist respectively of five (5) and three (3) deeper depressions (pools) paralleling the northwestsoutheast Konongo Scarp, which are disconnected below altitudes $792 \mathrm{~m}$ (north) and $789.4 \mathrm{~m}$ (south). Characteristic elevation-area and elevation-volume equations are segmented for lake below ridge altitude $(794.3 \mathrm{~m})$ whereas single relationships prevail for a single Lake Rukwa. Comparison of lake volumes estimated by refined and old equations indicated underestimation of lake stored volumes between $782.2 \mathrm{~m}$ and $805.65 \mathrm{~m}$ altitudes and overestimation thereafter by the old equations although the under/over-estimation remained within $10 \%$ between $801 \mathrm{~m}$ and $812 \mathrm{~m}$. Old elevation-area equations underestimate lake surface area of up to $796.8 \mathrm{~m}$, thereafter overestimate the lake area up to an altitude of $804.85 \mathrm{~m}$ and above this altitude underestimation re-appear. The old equations under/over-estimation, however, remains within $11 \%$ for altitudes between $794.3 \mathrm{~m}$ and $810 \mathrm{~m}$. The refined equations indicate surface areas of north and south lakes at ridge altitude to be $2,554.4$ and $837.1 \mathrm{~km}^{2}$, respectively forming a $3,391.5 \mathrm{~km}^{2}$ lake while at its highest recorded historical elevation of $804.69 \mathrm{~m}$, Lake Rukwa is $183 \mathrm{~km}$ long and 17-51 km wide occupying an area of 5,614.7 $\mathrm{km}^{2}$ (north: $4,409.8 \mathrm{~km}^{2}$; south: 1,204.9 $\mathrm{km}^{2}$ ) and containing 58.243 $\mathrm{km}^{3}$ of water (north: $44.318 \mathrm{~km}^{3}$; south: $13.925 \mathrm{~km}^{3}$ ). The developed characteristic equations can be used for water management studies of Lake Rukwa.
\end{abstract}

Keywords: Lake bathymetry; lake characteristic equations; Lake Rukwa; lake surface area; lake stored volume; shifted power models. 


\section{NTRODUCTION}

Lake Rukwa Basin is an internally draining basin located in south-west Tanzania (Figure 1). The basin covering an area of about 88,000 $\mathrm{km}^{2}$ within the Rift Valley, is bordered in the southeast by the Mbeya Range, in the west by the slopes of the Ufipa escarpment, and in the north-east by rocky cliffs and rolling hills which reach as high as $1,707 \mathrm{~m}$ at Mount Sange (Baker and Baker, 2002).

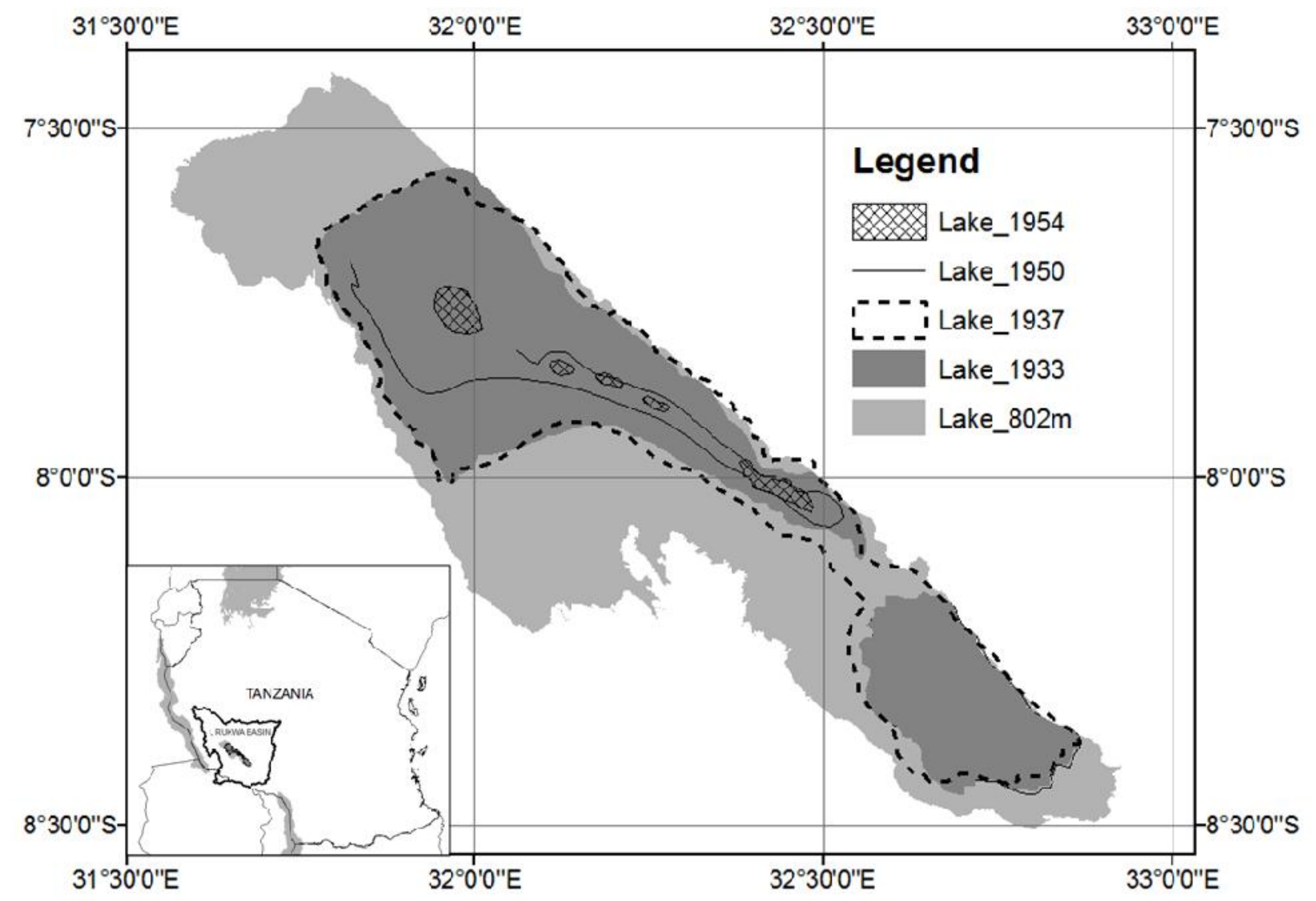

Figure 1: Documented extents of Lake Rukwa surface in the 1933-2018 period.

According to literature, Lake Rukwa has historically changed its size and shape significantly in the past. The changes in shape have indicated existence of pools, two separate large north and small south lake basins and a recent single lake. The lake has varied (Figure 1) between its smallest surface area as recently as in 1954 (Gunn, 1956) to its largest extent in the early 1990s. The length reported to vary between 135 and $180 \mathrm{~km}$ with an average width of $32 \mathrm{~km}$ (Lakepedia, 2016) with no details of its width provided. The pre 1955 information largely available in Gunn (1956) indicated in much of the 1873-1954 period, Lake Rukwa existed as two separate lake basins (the 1933 extent), which occasionally joined (the 1937 extent). The largest lake in the pre-1960s period was in 1937 followed perhaps by the 1882 and 1905 extents while small surface areas correspond to very low or complete dry north lake basin in 1889-1899, 1920 and 1948-1954. A complete dry lake Rukwa (north \& south lakes) has been reported around 1770 and a dry north lake basin in 1815-1835 (Nicholson, 1999) while a dry north lake was observed in 1954 corresponded to small 5 pools (Figure 1). Moreover, low lake depths have been reported in several other years including 1873, 1889-1899, 1914, 1929, 1948-1951, 1953 (Nicholson, 1999; Gunn, 1956). The lake had also experienced notable periods of high stand including the 1875-1882, 
1904-1905 and 1937-1942. Since the dry mid1950s, the lake has constantly risen to its highest level in 1989-1995 and decrease thereafter.

Available limited literature on Lake Rukwa indicates variable lake characteristics (length, width, depth, surface area) of the lake in the historical times. The average lake depth is reported at 3-5 m while the maximum depth in the south basin is reported at $15 \mathrm{~m}$ (World Lakes, 2016). However, the total surface area of Lake Rukwa at $800 \mathrm{~m}$ is differently reported in the literature $\left(2,600 \mathrm{~km}^{2}\right.$ - Britannica, 2016; $5,760 \mathrm{~km}^{2}$ in February 2007 - Wikipedia,
2016; 1,966 $\mathrm{km}^{2}$ - Lakepedia, 2016 and 5,200 $\mathrm{km}^{2}-$ MoW-URT, 2014).

Bathymetric survey of the lake has been carried out in March 2014 by the Lake Rukwa Basin Office in collaboration with the Department of Water Resources Engineering of the University of Dar es Salaam and iWASH programme (Tanzania) and it provides, for the first time ever, information of lake bottom topography although at a coarse spacing of surveyed transects. LRBWB-MoW (2014) used bathymetric data to develop characteristic elevation-area-volume equations for Lake Rukwa, which are given by equations (1a) and 1(b).

$$
V=\left\{\begin{array}{l}
0.00354(E L-785.9852)^{2.8154} \\
0.000019685(E L-784.5818)^{5.43221} \\
1.1865(E L-791.38525)^{1.49868}
\end{array}\right.
$$

$786.3 \leq \mathrm{EL} \leq 789.5 \mathrm{~m}$

$789.5<E L \leq 792.6 m$

$\mathrm{EL}>792.6 \mathrm{~m}$

$$
A=\left\{\begin{array}{cl}
6.616182(\mathrm{EL}-785.729)^{204543} & 786.3<E L \leq 789.3 \mathrm{~m} \\
98.5706(\mathrm{EL}-788.497)^{1.5473 .2} & 789.3<E L \leq 791.7 \mathrm{~m} \\
1796.858(\mathrm{EL}-791.699)^{0.51187} & 791.7<E L \leq 800.9 \mathrm{~m} \\
5634.984+0.12418(\mathrm{EL}-786.3) & 801.0<E L \leq 803.8 \mathrm{~m}
\end{array}\right.
$$

where $E L$ is the water surface elevation above mean sea level (m).

The above developed characteristic elevationarea and elevation-volume equations for Lake Rukwa suffer from two major setbacks in their usage. The first problem is that the equations have been developed for a single Lake Rukwa and therefore are inapplicable at times of low lake stands when the lake divides into its separate north and south basins.

The second problem arises from interpretation of no water altitude $\left(h_{o}\right)$ as estimated in developed elevation-area and elevation-volume relationships. The relationships closely predict this to be around 785.73-785.99 $\mathrm{m}$ indicating the lowest bottom point as $785.7 \mathrm{~m}$. However, re-analysis of all available bathymetric data for each transect revealed that the two lake basins have different deepest sounded points, which were $784.36 \mathrm{~m}$ (north) and $778.37 \mathrm{~m}$ (south). Consequently, the depicted $h_{o}$ of the developed relationships could be indicating the lowest point of the north basin. This resulted from the weakness of the selected 2,605 bathymetric data points used in developing these equations (deepest point: $15.6 \mathrm{~m}$ ) (LRBWB-MoW, 2014) against a total of 107,938 available soundings (deepest: $22.5 \mathrm{~m}$ ).

Moreover, lake surface areas estimated from developed elevation-area equations differ from those digitized from maps. Lake shoreline at $802 \mathrm{~m}$ altitude digitized from available 1:50,000 topographical maps of 1985 gives a total lake surface area of $5,259.81 \mathrm{~km}^{2}$ while estimated by the equations as $5,636.93 \mathrm{~km}^{2}$. The boundary shoreline used in developing these early study equations was digitized from Google Earth image and assumed to correspond to the $800.8 \mathrm{~m}$ lake surface altitude recorded during the March 2014 bathymetric survey, the fact that could not be verified. Elevation-area equations are further 
inapplicable for altitudes exceeding $803.8 \mathrm{~m}$ and consequently lake surface areas at higher lake stands of 1989-1995 and 1998 cannot be estimated using these equations.

Owing to availability of bathymetric sounding data within the lake and inadequacy of developed characteristic equations for the lake, this study aimed at improving lake bathymetric analysis by incorporating lake shorelines digitised from different existing maps and spot heights to a higher altitude of $820 \mathrm{~m}$. Moreover, this study uses improved lake bathymetry to establish of new elevation-area and elevation-volume equations for Lake Rukwa taking into consideration existence of multiple lake basins at low stands.

\section{METHODS AND MATERIALS}

\section{Lake Boundaries and Bathymetric Data}

Lake boundaries were obtained from available digitised and geo-referenced 1:50,000 topographical maps and the December 1954 Lake Rukwa map of the Directorate of Colonial Survey (DCS) (Gunn, 1956). Topographical maps gave the $802 \mathrm{~m}$ lake shoreline and $820 \mathrm{~m}$ first land contour from the lake shoreline. The DCS hardcopy map in the Gunn (1956) gave several lake surface extents between 1933 and 1954. The map was extracted, converted to an image file and geo-referenced using coordinates of several locations on the map. The 1947, 1950 and 1954 extents were directly digitised from the map while the 1933 and 1937 lake surface extents were extracted from the map following descriptions in the accompanying text (Gunn, 1956).

The two types of data required for development of lake elevation-area-volume relationships were lake water depths (converted to surface water elevations) and lake shoreline boundaries. Water depths of Lake Rukwa were primarily obtained from lake bathymetric survey carried out in March 2014. Bathymetric (depth sounding) data covers only the current inundated part of the lake below $800.8 \mathrm{~m}$ altitude (Figure 2) and were converted to lake bottom altitudes using a known benchmark at the Lake Mbangala gauging station and lake stage measurements at Mbangala during the survey.

Water depth variation along shoreline transects parallel to the Konongo scarp indicated consistent deep-water producing lake shorelines parallel to the scarp and therefore additional points were generated by linear interpolation of lake surface altitudes between adjacent transects along the unsurveyed shoreline (Figure 2). Spots heights of random land points between the $802 \mathrm{~m}$ lake shoreline and the first $820 \mathrm{~m}$ land contour line were read from 1:50,000 topographical maps and recorded (Figure 3). Gunn (1956) gave spot measured depths of Lake Rukwa at different locations between 1934 and 1954, which were used in verification of interpolated lake bathymetry.

\section{Improving Lake Bathymetry}

The 2014 bathymetric survey of Lake Rukwa used an echo sounder mounted at the rear bottom of the boat to record water depths every second. The boat cruising speed was maintained at $10-12 \mathrm{~km} / \mathrm{hr}$ providing soundings at an approximately interval of $2-4 \mathrm{~m}$. At some instances when the sounder went out of water due to high waves, the soundings were not recorded. A total number of 107,938 good soundings were finally retained. Owing to this large number of closely sounded depths of the lake, it was necessary to select few sounded depths representing lake bottom altitudinal variations, which were combined with spot heights to define an improved lake topography raster. The selection process of representative lake bathymetric points used three criteria for each surveyed transect i) minimum and maximum sounded depths were selected, ii) sounded depths taken for points in which depths differences equalled or exceeded $0.2 \mathrm{~m}$ and iii) selected points were constrained to stretch the entire length of the transect across the lake. In cases when the second criterion eliminated a certain portion of the transect, few points were retained at a specified interval to bridge the gap. These selection criteria were applied to each of the 12 perpendicular and 12 
parallel to shoreline transects. These criteria retained 13,934 sounded depths (Figure 3). The selected bathymetric points show the deepest locations lie mostly close to the eastern shore coinciding with locations of the 1954 pools in the north lake basin. The elevation at these points were combined with spot heights to define land altitudes to $820 \mathrm{~m}$ (Figure 3).

Improvement of the bathymetry was necessary in order to improve quality of the contours defining shapes of lake surface. This required constraining of interpolation by introduction of manually interpolated depths between the adjacent transects in northwest and southeast parts of the lake and along the eastern shore along the Konongo Scarp (Figure 3). The aim was to rectify unrealistic inward curves in contour shapes at these locations revealing themselves as arcs from shoreline along the Konongo scarp (Figure 4a) at places were the lake surface shorelines depicted in historical parallel to the scarpment. This was done by constraining interpolation to improve representation of the shoreline shape as in historical digitised maps (Figure $4 b$ ).

\section{Assessing adequacy of improved bathymetry to define lake shapes}

Assessment of adequacy of improved lake bathymetry was carried out by comparison of shapes and areas of the lake from contour generated lake extents against digitised historical extents. Different interpolation methods included in the ArcGIS Spatial Analyst Tool were used to develop raster data from these point altitudes and contours created at an interval of $0.1 \mathrm{~m}$ from the rasters to define shapes of lake surface. A comparison was then made by plotting on the same map contours and digitised lake surfaces and comparing shapes of contours closest to historical lake shapes.

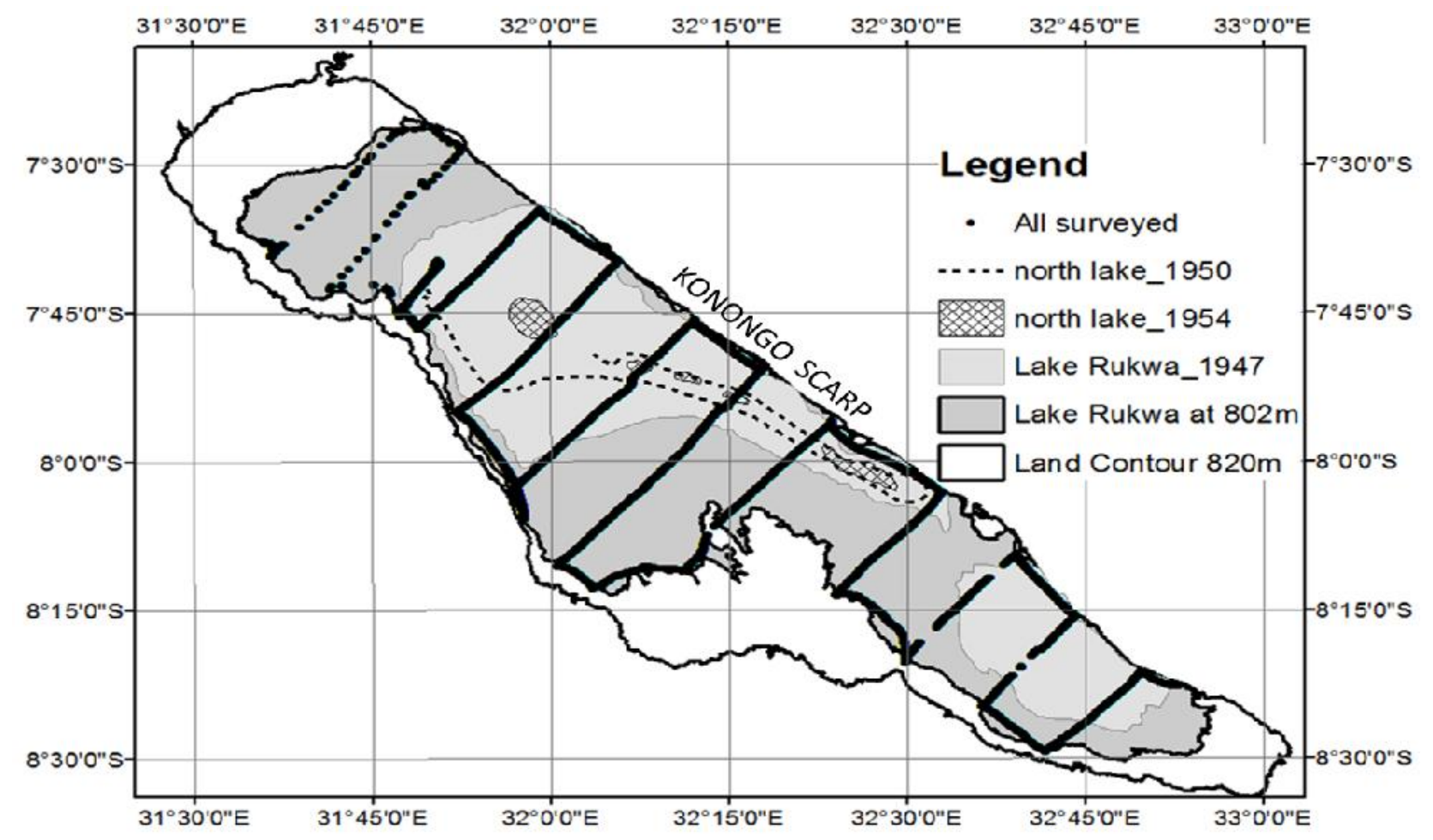

Figure 2: Bathymetric sounded data at surveyed transects in Lake Rukwa. 


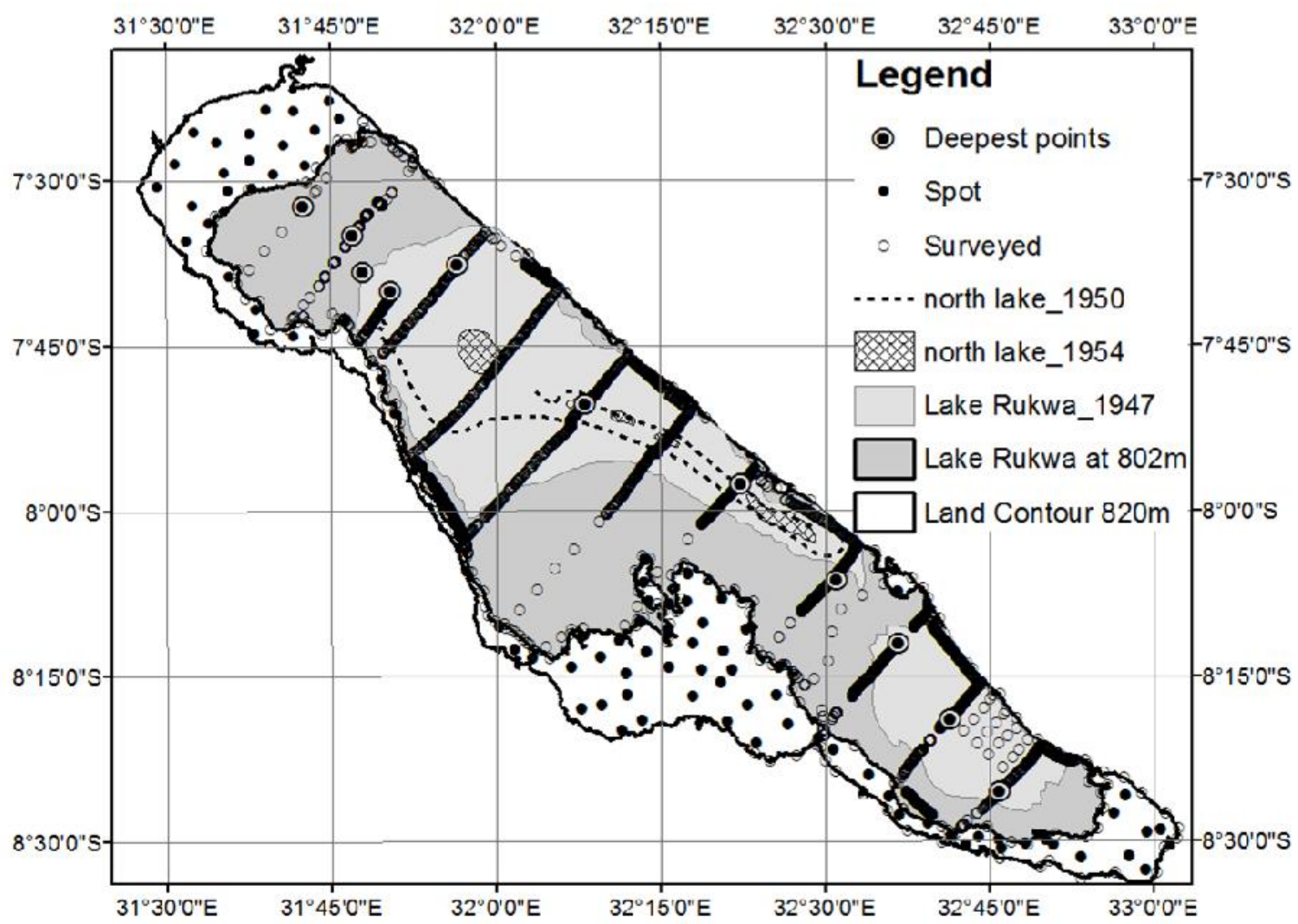

Figure 3: Selected bathymetric points, spot heights and lake boundaries for analysis.

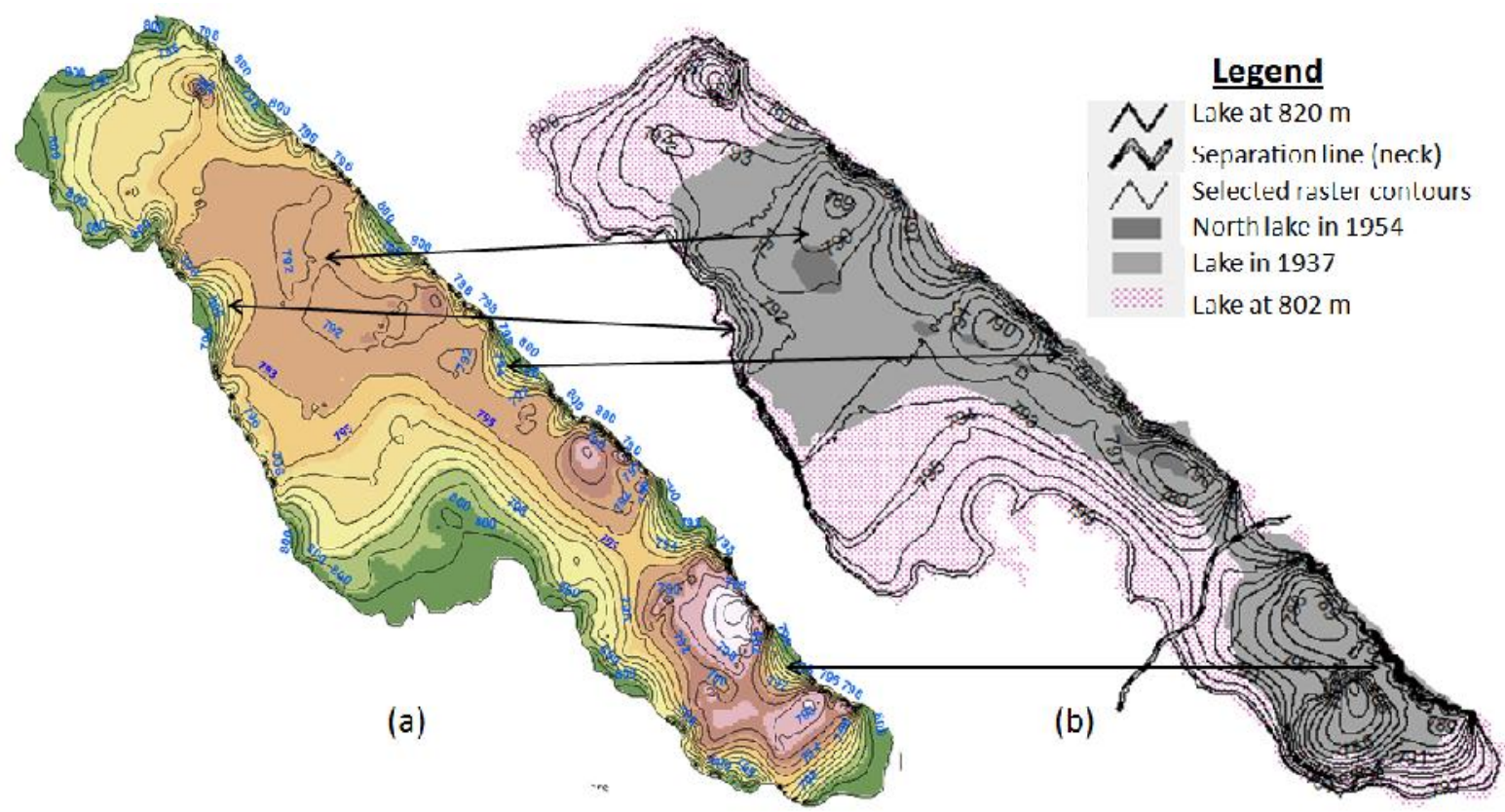

Figure 4: a) Original and b) refined lake bathymetry of Lake Rukwa.

An assessment further compared lake areas of digitised lake shapes and closest contours in which closeness was evaluated by the magnitude of standardised difference (Di) proposed by URT-MoW (2017), which provides finer classes of $D_{i}$ than Ritcher et al. 
(1998). The standardised difference was computed as the ratio of the surface area difference between model estimated and digitised surface area of the lake to digitised lake surface area. It is considered small when its absolute value is below $10 \%$, moderate between $10 \%$ and $20 \%$, slightly large between $20 \%$ and $30 \%$ and large above $30 \%$. Raster generating method resulting into contours approaching digitised lake shapes and producing the least difference between areas was retained for extraction of lake surface areas and volumes using a Surface Volume of the Functional Surface (3D Analyst Tools) in ArcGIS. Extraction of surface areas and volumes of lake basins (north, south) before joining into a single lake involved defining a ridge altitude from the contours of the selected raster, clipping the raster to represent south and north basins and extraction of their respective surface areas and volumes.

\section{Lake characteristic equations}

Change-point analysis using Pettitt test, Lee and Heighinian test and Hubert autosegmentation procedure included in the Khronostat Software (IRD-HSM, 2002) was carried on extracted elevation-area and elevation-volume data pairs for lake basins and entire lake to identify change points and segmentation of the data sets. Shifted power model was fitted to each segment to obtain the best fit mathematical models. The shifted power model used is shown by equation (2).

$$
y=k\left(h-h_{o}\right)^{x}
$$

where $y$ is dependent variable (lake surface area, volume), $h$ is independent variable (lake water surface altitude), $h_{o}$ is the no water altitude for a given lake segment, $k$ is the obtained from the intercept on the $\log y$-axis and $x$ is the slope of the $\log y \log \left(h-h_{\mathrm{o}}\right)$ plot. CurveExpert Professional software (Hyams, 2011) was used to obtain values of parameters $k, h_{o}$ and $x$ of the best fitting curve to data. Model fitting efficiency was assessed by maximising the Nash-Sutcliffe coefficient of efficiency (NSE) comparing observed and estimated lake areas or volumes.

\section{RESULTS AND DISCUSSION}

\section{Improved Lake Bathymetry and its Features}

\section{Adequacy of the bathymetry}

Contours generated from a refined raster bathymetry of Lake Rukwa (Figure 4b) shows an improvement in the way bathymetry is presented for the lake compared to lake shapes from contours generated using an old bathymetry (Figure 4a). Assessment of the lake shapes depiction by raster generated contours considered improvements in capturing main features of Lake Rukwa including the north lake pools, straight lake shore along the Konongo Scarp, dividing ridge between north and south lake basins and westward linear expansion of the lake on its northwest side. The refined bathymetry largely reduced curves in the northwest and southeast parts of the lake as well as straightening lake shores along the Konongo Scarp as in old maps (Gunn, 1956). Generated contours representing lake surface extents at different altitudes largely reproduced the $802 \mathrm{~m}$ shoreline of Lake Rukwa (Figure $4 b)$.

The new bathymetry captures lake altitudes below $792 \mathrm{~m}$ in the north and $790 \mathrm{~m}$ in the south (Figure $4 \mathrm{~b}$ ), which were not captured by the original bathymetry (Figure 4a). The north lake is portrayed as disconnected lake by the $792 \mathrm{~m}$ altitude of the old bathymetry while connected in the refined bathymetry. Despite capturing locations of the 1954 pools as reported in Gunn (1956), refined bathymetry could not capture their sizes particularly of three small central pools (Figure $4 \mathrm{~b}$ ) giving larger pools than recorded fact reflected in a slightly large difference between digitised and raster generated lake sizes (Table 1). This calls for improvement of bathymetric data along the NW-SE direction within the pool area. Comparison of the contours and digitised lake surface further indicates $792 \mathrm{~m}, 792.7 \mathrm{~m}$ and $793.2 \mathrm{~m}$ contours to approximately represent the 1950, 1947 and 1933 extents of Lake 
Rukwa while the 1954 pools correspond to a altitude contour of $788.5 \mathrm{~m}$.

Contours indicates Lake Rukwa is separated into north and south basins at $794.3 \mathrm{~m}$, above which a single lake prevails and the altitude was considered to represent altitude of the separation ridge between the lake basins. The ridge was then adjusted to follow the dry crest between north and south lake basins defined by the passing route up to old right bank of River Momba on the old maps reported in Gunn (1956). The separation ridge was thereafter used to partition the bathymetry raster of Lake Rukwa into north and south lakes from which shapes, surface areas and volumes of the two lake basins were extracted.

Raster generated lake surface areas for altitudes $792 \mathrm{~m}, 792.7 \mathrm{~m}, 793.2 \mathrm{~m}$ and $802 \mathrm{~m}$ defining historical lake extents and $820 \mathrm{~m}$ land contour remarkably matched digitised historical lake sizes (Table 1). Better matching raster generated lake surface areas at altitudes above the 1954 pool level suggests refined lake bathymetry is capable of depicting lake characteristics above such an altitude $(788.5 \mathrm{~m})$ and below which bathymetry needs more refinements.

\section{Lake characteristic sizes}

Resulting lake surface contours developed from topography raster indicate that Lake Rukwa is about $184 \mathrm{~km}$ long and 17-51.2 km wide at its historical highest elevation (Surface water altitude: $804.7 \mathrm{~m}$ ) having a surface area of $5,611.75 \mathrm{~km}^{2}$ and average depth of $10.37 \mathrm{~m}$ (max depth: $22.49 \mathrm{~m}$, south basin). The lake is currently at $800.8 \mathrm{~m}, 16-49 \mathrm{~km}$ wide extending $177 \mathrm{~km}$ with a total surface area of $4,993.92$ $\mathrm{km}^{2}$ and an average depth of $7.48 \mathrm{~m}$ (max interpolated depth: $18.6 \mathrm{~m}$, south basin). Length of Lake Rukwa reported in literature (Lakepedia, 2016) lies within the measured and raster generated lake extent. However, lake depths and surface areas have been largely underestimated. The average lake depth has been reported at 3-5 m while the maximum depth in the south basin reported at $15 \mathrm{~m}$ (World Lakes, 2016). The reported average depth range is almost half that derived from bathymetric measurements and analyses in this study while the maximum depth of the north basin is given for the first time.

Of the two lake basins, the north basin is the largest being $127 \mathrm{~km}$ long and $23-51 \mathrm{~km}$ wide at $804.7 \mathrm{~m}$ altitude having a surface area of $4,406.85 \mathrm{~km}^{2}$ and average depth of $10.04 \mathrm{~m}$ (max interpolated depth: $17.7 \mathrm{~m}$ ). The south basin is small, $17-31 \mathrm{~km}$ wide extending $57 \mathrm{~km}$ at $804.7 \mathrm{~m}$ altitude with a surface area of 1,205 $\mathrm{km}^{2}$ and average depth of $11.6 \mathrm{~m}$ (max interpolated depth: $22.49 \mathrm{~m}$ ). At the current surface altitude of $800.8 \mathrm{~m}$, north and south basins are 3,925 and $1,082 \mathrm{~km}^{2}$ large respectively with average depths of $7.15 \mathrm{~m}$ (north) and $8.9 \mathrm{~m}$ (south) and maximum depths of $13.8 \mathrm{~m}$ (north) and $18.6 \mathrm{~m}$ (south). The 800 $\mathrm{m}$ altitude contour gives total area of Lake Rukwa of $4,846.4 \mathrm{~km}^{2}$, which is reported as $2,600 \mathrm{~km}^{2}$ (Britannica, 2016), 5,760 $\mathrm{km}^{2}$ in February 2007 (Wikipedia, 2016), 1,966 km² (Lakepedia, 2016) and closely estimated from the graphical relationship as $5,200 \mathrm{~km}^{2}$ (MoWURT, 2014). The area given by Wikipedia corresponds to an estimated lake surface altitude of $805.7 \mathrm{~m}$, which is outside the February 2007 observed altitude range of 800$801 \mathrm{~m}$ (LEGOS/GEOS, 2016) and estimated as $801.0 \mathrm{~m}$ (Valimba, 2015). 
Table 1: Comparison of measured and estimated lake surface areas.

\begin{tabular}{|c|c|c|c|c|c|c|c|}
\hline \multirow{2}{*}{ Lake } & Year & & 1933 & 1937 & 1950 & 1954 & \\
\hline & Alt (m) & 802 & 792.7 & 793.2 & 792 & 788.5 & 820 \\
\hline \multirow{4}{*}{ North } & Digitised & $4,131.6$ & $1,860.8$ & $1,985.9$ & - & 41.1 & $5,763.6$ \\
\hline & Contour & $4,081.6$ & $1,782.2$ & $2,082.6$ & $1,305.9$ & 53.4 & $5,597.0$ \\
\hline & Equation & $4,079.6$ & $1,793.0$ & $2,095.0$ & $1,249.9$ & 52.6 & $5,700.3$ \\
\hline & $D_{i}$ & $-1.3 \%$ & $-3.6 \%$ & $5.5 \%$ & & $28.1 \%$ & $-1.1 \%$ \\
\hline \multirow{4}{*}{ South } & Digitised & $1,128.2$ & 625.8 & 715.0 & 576.9 & - & $1,599.6$ \\
\hline & Contour & $1,114.6$ & 660.2 & 718.2 & 588.4 & 288.4 & $1,566.9$ \\
\hline & Equation & $1,120.6$ & 680.3 & 716.7 & 591.0 & 234.5 & $1,563.4$ \\
\hline & $D_{i}$ & $-0.7 \%$ & $8.7 \%$ & $0.3 \%$ & & & $-2.3 \%$ \\
\hline \multirow{4}{*}{ Entire lake } & Digitised & $5,259.8$ & $2,486.6$ & $2,700.8$ & - & & $7,363.2$ \\
\hline & Contour & $5,196.2$ & $2,442.4$ & $2,800.8$ & $1,894.2$ & 341.8 & $7,164.0$ \\
\hline & Equation & $5,204.3$ & - & $2,811.7$ & - & - & $7,248.2$ \\
\hline & $D_{i}$ & $-1.1 \%$ & & $4.1 \%$ & & & $-1.6 \%$ \\
\hline
\end{tabular}

\section{Lake Characteristic Equations}

\section{Single lake}

According to bathymetric analysis, a single Lake Rukwa exists above an altitude of 794.3 $\mathrm{m}$ and lake water surface areas and volumes were extracted for elevations above this altitude (Figure 5). Change-point analyses were carried out on these data and by data fitting revealed single relationships between elevation $(h)$ and area $(A)$ or volume $(V)$ depicted to be

$$
\begin{aligned}
& A=2407.94(\mathrm{~h}-791.6)^{0.32937} \\
& V=1.537436(\mathrm{~h}-790.5)^{1.369103}
\end{aligned}
$$

The fitted models reproduced well lake surface areas and volumes (Figure 5) giving fitting efficiencies (NSE) of $99.9 \%$ for both lake surface area and lake volumes and are considered adequate. At an altitude of $794.3 \mathrm{~m}$ and below, Lake Rukwa exists as two separate lakes, the north and south lake basins with the former being the largest.

\section{North lake basin}

Lake water surface areas and volumes were extracted from north lake basin raster at an interval of $0.1 \mathrm{~m}$ from $787 \mathrm{~m}$ to $794.3 \mathrm{~m}$ altitudes. Changing shapes from concave (787$792 \mathrm{~m}$ ) to convex (between 792 and $794 \mathrm{~m}$ ) of the elevation-area plot indicates double curvature suggesting two different relationships (Figure 6). Change-point analysis confirmed the existence of two segments in the elevationarea relationship with a change in the relationship occurring at $792.0 \mathrm{~m}$ altitude. Despite visual analysis of elevation-volume plot indicating rather a single curve, change point analysis segmented elevation-volume relationship into two segments with a change at $792.0 \mathrm{~m}$ altitude. This is the altitude representing a single north lake basin below which north lake exists into constituent pools. The best fitted power models with NSE exceeding 95\% representing the segmented relations as shown by equations $4(\mathrm{a})$ and $4(\mathrm{~b})$. 


$$
\begin{aligned}
A & =18.0937717(\mathrm{~h}-787.0)^{2.6315008} \\
& =1912.332852(\mathrm{~h}-791.9)^{0.327343 .8} \\
V & =0.002743216(\mathrm{~h}-786.7)^{3.879379} \\
V & =0.037598033(\mathrm{~h}-788.2)^{2.8454124}
\end{aligned}
$$

\begin{tabular}{|c|c|c|c|c|}
\hline \multirow[b]{2}{*}{ Alt } & \multicolumn{2}{|c|}{ Area $\left(m^{2}\right)$} & \multicolumn{2}{|c|}{ Volume $\left(\mathrm{m}^{3}\right)$} \\
\hline & Measured & Fitted & Measured & Fitted \\
\hline 820.0 & , 163.963 & $7,248.200$ & 1.58 .7 .38 & 158.396 \\
\hline 815.0 & 849.038 & $6,799.999$ & 123.054 & 122.869 \\
\hline 810.0 & 320.264 & $6,281.909$ & 0.045 & 89.931 \\
\hline 806.0 & $5,809.284$ & $5,794.119$ & 65.753 & 65.712 \\
\hline 805.5 & $5,741.677$ & $5,726.978$ & 2.866 & 2.833 \\
\hline 805.0 & $5,672.815$ & $5,658.196$ & 0.012 & 59.989 \\
\hline 801.5 & $3,603.892$ & $3,381.66 /$ & $3 / .193$ & $3 / .180$ \\
\hline 801.0 & b, $333.5 / 1 /$ & $3,31 b .21 /$ & $31.10 i$ & 31.109 \\
\hline 803.5 & $5,156.998$ & $3,110.900$ & 31.660 & $31.6 / 3$ \\
\hline 803.0 & $5,3 / 2.903$ & $3,361.393$ & 8.952 & 8.980 \\
\hline 802.5 & $5,289.031$ & $5,285.597$ & 85 & 46.324 \\
\hline 802.0 & $5,196.228$ & 5.201 .331 & 8.661 & 13.708 \\
\hline 801.5 & 5,10 & & & 41.134 \\
\hline 801.0 & $5,016.231$ & $5,033.570$ & 557 & 38.603 \\
\hline 800.5 & $4,930.059$ & $4,943.577$ & 073 & 36.116 \\
\hline 800.0 & $4,840.440$ & $4,850.110$ & 3.630 & 33.674 \\
\hline 792.5 & $4,742.748$ & 4,752 & 1.234 & 31.279 \\
\hline 799.0 & 4,643.579 & 4,6 & 28.889 & 28.932 \\
\hline 798.5 & $4,540.196$ & $4,545.104$ & 26.593 & 26.636 \\
\hline 798.0 & $4,428.397$ & 4.433 .562 & 24.351 & 24.392 \\
\hline 797.5 & $4,304.138$ & $4,315.993$ & 22.169 & 22.202 \\
\hline 797.0 & $4,174.117$ & $4,191.514$ & 20.049 & 20.069 \\
\hline 796.5 & $4,044.207$ & $4,059.016$ & 17.996 & 17.995 \\
\hline 796.0 & $3,895.478$ & $3,917.073$ & 16.011 & 15.984 \\
\hline 79.5 .5 & $3,7.57 .624$ & $3,763.805$ & 14.099 & 14.039 \\
\hline 79.5 & $3,611.870$ & $3,596.653$ & 17.257 & 12.165 \\
\hline 794.5 & $3,448.767$ & 3411.982 & 10.491 & 10.365 \\
\hline 794.0 & $3,240.538$ & $3,204.354$ & 8.817 & 8.646 \\
\hline
\end{tabular}

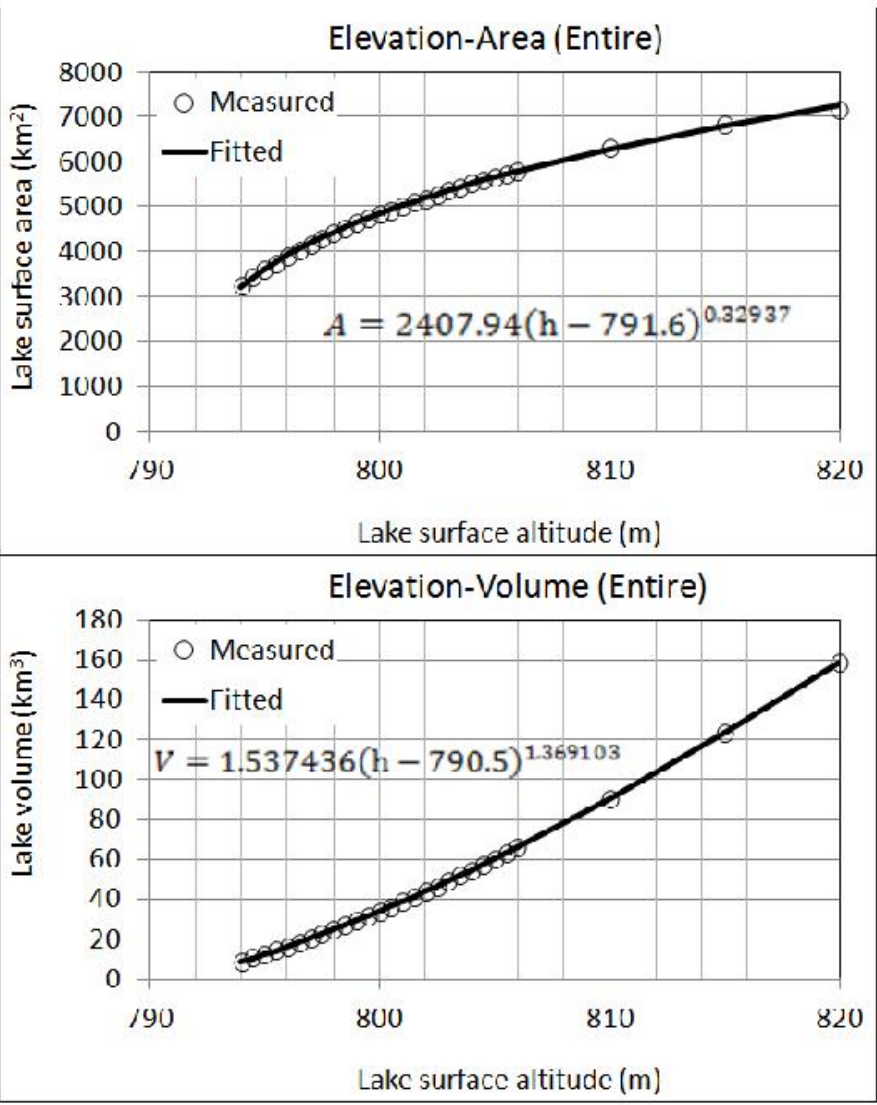

Figure 5: Elevation-area-volume data and equations for Lake Rukwa above $794.3 \mathrm{~m}$.

\section{South lake basin}

Lake water surface areas and volumes were extracted from south lake basin raster at an interval of $0.1 \mathrm{~m}$ from $782.0 \mathrm{~m}$ to $794.3 \mathrm{~m}$ altitudes. Elevation-area plot indicates double curvature suggesting existence of two or more relationships (Figure 7). Change-point analysis identified four segments in the elevation-area relationship with changes in the relationship at $785.5 \mathrm{~m}, 787.0 \mathrm{~m}$ and $789.5 \mathrm{~m}$ altitudes. Despite visual analysis of elevation-volume plot indicating rather a single curve, change point analysis identified two segments in the elevation-volume relationship with a change occurring at $789.3 \mathrm{~m}$ altitude.
The south lake basin exists as an oval single lake up to $785.1 \mathrm{~m}$ altitude when this single central lake pool changes its shape to a bowl like with a large increase at its southern part. This single pool exists up to an altitude of $787.0 \mathrm{~m}$ above which a north pool forms within the south lake basin and the two north and central pools combine at $788.9 \mathrm{~m}$ to form a larger pool of the south lake. At $788.7 \mathrm{~m}$, the third south pool starts forming and combines with the rest at $789.3 \mathrm{~m}$ to form a single south lake basin. Therefore, the three change points define the three critical stages of formation of a single south basin of Lake Rukwa. The best fitted power models with NSE exceeding $96 \%$ representing the segmented relations as shown by equations 5 (a) and 5(b). 


$$
\begin{aligned}
A & =4.45986304(\mathrm{~h}-782.2)^{2.03351915} h \leq 785.1 \mathrm{~m} \\
& =19.545048(\mathrm{~h}-783.3)^{1.2083659} \quad 785.1 \mathrm{~m}<h \leq 787.0 \mathrm{~m} \\
& =0.24381281(\mathrm{~h}-781.6)^{3.52270204} \quad 787.1 \mathrm{~m}<\mathrm{h} \leq 789.3 \mathrm{~m} \\
& =8.324284656(\mathrm{~h}-781.4)^{1.80129237} \quad h>789.3 \mathrm{~m} \\
V & =0.000244721(\mathrm{~h}-781.2)^{3.71515183} h \leq 789.3 \mathrm{~m} \\
V & =0.029526229(\mathrm{~h}-785.2)^{2.16089088} \mathrm{~h}>789.3 \mathrm{~m}
\end{aligned}
$$

\section{Comparison of old and refined characteristic equations for lake surface areas and volumes}

Comparison of lake surface areas and volumes estimated using old equation (LRBWB-MoW, 2014) (see equation 1) and refined characteristics equations (see equations 3 to 5) indicates large differences of lake areas and volumes below a ridge altitude $(794.3 \mathrm{~m})$ (Table 2). Old equations give a lake volume of $0.004 \mathrm{~km}^{3}\left(4 \mathrm{Mm}^{3}\right)$ while it is over 40 times as estimated by refined equations $\left(163 \mathrm{Mm}^{3}\right)$. The percent difference of estimated stored volumes between the old and refined equations decreases with increasing lake surface altitude to below $2 \%$ at the historical highest lake surface altitude of $804.69 \mathrm{~m}$ (volume is 58.2 $\mathrm{km}^{3}$ ) in early 1990s. This decreasing difference persists up to an altitude of $805.7 \mathrm{~m}$ above which underestimation re-appear. Despite being developed using data up to an altitude of $803.8 \mathrm{~m}$, the old elevation-volume equation can estimate lake stored volume between $801 \mathrm{~m}$ and $812 \mathrm{~m}$ to within $10 \%$ of error making them equally useful. Between high stand of the early 1990 s and current stand $(\sim 800 \mathrm{~m}$, volume is $33.7 \mathrm{~km}^{3}$ ), Lake Rukwa has lost about 24.5 $\mathrm{km}^{3}$ of water.

Old characteristic equations largely underestimate lake surface areas below the 792 $\mathrm{m}$ altitude and generally underestimation reduces with increasing altitude of the lake surface (Table 2) up to an altitude of $796.8 \mathrm{~m}$ where the difference becomes zero. Thereafter, old equations start overestimating lake surface area to an altitude of $804.85 \mathrm{~m}$ above which underestimations restart. However, the under/over estimation of the lake surface area by the old equation is within $11 \%$ for altitudes between $794.3 \mathrm{~m}$ and $810 \mathrm{~m}$ indicating their usefulness when Lake Rukwa exists as a single lake. 
Development of Improved Characteristic Equations for Lake Rukwa in Tanzania

\begin{tabular}{|c|c|c|c|c|}
\hline \multirow[b]{2}{*}{ Alt } & \multicolumn{2}{|c|}{ Area $\left(m^{2}\right)$} & \multicolumn{2}{|c|}{ Volume $\left(m^{3}\right)$} \\
\hline & Measured & Fitted & Measured & Fitted \\
\hline 14.3 .1 & $2,778.81,3$ & $2,740.046$, & 4.41 .3 & 4.47 .3 \\
\hline 14.3 .11 & $1,961.44 /$ & $1,481, \ldots 94$ & 3.361 & 3.344 \\
\hline 792.5 & $1,663.587$ & $1,636.504$ & 2.457 & 2.452 \\
\hline 792.0 & $1,305.881$ & $1,249.883$ & 1.715 & 1.731 \\
\hline 791.5 & 955.790 & 947.236 & 1.151 & 1.167 \\
\hline 791.0 & 667.676 & 691.785 & 0.751 & 0.759 \\
\hline 790.5 & 477.827 & 488.928 & 0.467 & 0.467 \\
\hline 790.0 & 323.938 & 325.892 & 0.270 & 0.269 \\
\hline 782.5 & 201.677 & 201.701 & 0.140 & 0.141 \\
\hline 789.0 & 112.153 & 112.122 & 0.064 & 0.065 \\
\hline 788.5 & 53.429 & 52.591 & 0.025 & 0.025 \\
\hline 788.0 & 21.014 & 18.094 & 0.008 & 0.007 \\
\hline 787.5 & 7.156 & 2.920 & 0.001 & 0.001 \\
\hline 787. & & & 0.000 & 0.00 \\
\hline
\end{tabular}

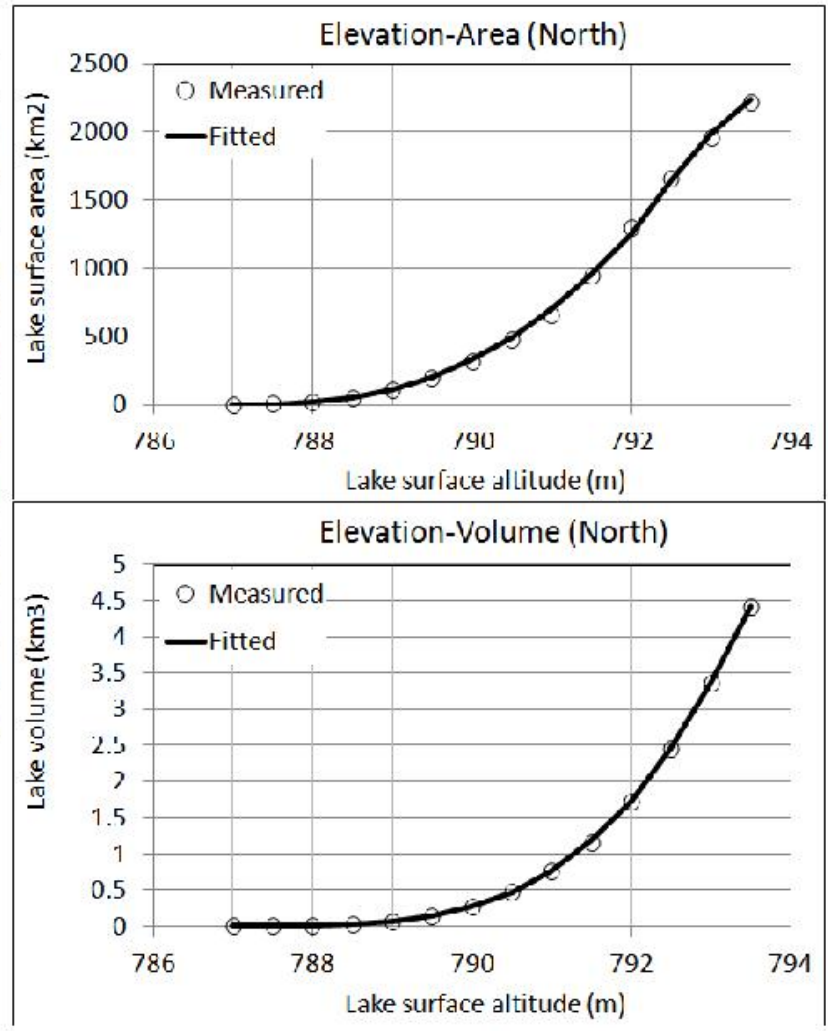

Figure 6: Elevation-area-volume data and equations for north basin of Lake Rukwa.

\begin{tabular}{|c|c|c|c|c|}
\hline \multirow[b]{2}{*}{ Alt } & \multicolumn{2}{|c|}{ Area $\left(m^{2}\right)$} & \multicolumn{2}{|c|}{ Volume $\left(\mathrm{m}^{\mathrm{9}}\right)$} \\
\hline & Measured & Fitted & Measured & Fitted \\
\hline 793.5 & 743.475 & 746.171 & 2.850 & 2.848 \\
\hline 793.0 & 696.270 & 691.696 & 2.489 & 2.490 \\
\hline 792.5 & 639.389 & 639.065 & 2.156 & 2.157 \\
\hline 792.0 & 588.351 & 588.295 & 1.819 & 1.850 \\
\hline 791.5 & 5.36 .081 & 5.39 .403 & 1.569 & $1.56,8$ \\
\hline 791.0 & 191.750 & 192.107 & 1.312 & 1.311 \\
\hline | & $449.3 / 9$ & $44 i .326$ & $1.0 / 1$ & $1.0 / 8$ \\
\hline 790.0 & 404.043 & 404.181 & 0.863 & 0.870 \\
\hline 789.5 & 351.239 & 355.103 & 0.673 & 0.685 \\
\hline 789.0 & 288.404 & 282.358 & 0.511 & 0.524 \\
\hline 788.5 & 213.840 & 220.747 & 0.388 & 0.386 \\
\hline 788.0 & 169.851 & 169.416 & 0.293 & 0.295 \\
\hline 787.5 & 129.597 & 127.254 & 0.218 & 0.222 \\
\hline 787.0 & 94.445 & 94.445 & 0.163 & 0.163 \\
\hline 786.5 & 79.178 & 79.178 & 0.119 & 0.116 \\
\hline 786.0 & 64.405 & 64.405 & 0.083 & 0.080 \\
\hline 183.5 & 30.131 & 50.351 & 0.053 & 0.053 \\
\hline 785.0 & 36.640 & 36.193 & 0.033 & 0.033 \\
\hline 781.5 & 21.618 & 21.261 & 0.018 & 0.020 \\
\hline$/ 84.1)$ & 14.164 & $14 . / 3 /$ & 0.0118 & (1.011 \\
\hline 783.5 & 7.271 & 7.604 & 0.003 & 0.005 \\
\hline 783.0 & 2.256 & 2.833 & 0.001 & 0.002 \\
\hline 782.5 & 0.461 & 0.386 & 0.000 & 0.001 \\
\hline 782.4 & 0.292 & 0.169 & 0.000 & 0.000 \\
\hline 782.3 & $0.1 G_{1}$ & 0.041 & 0.000 & 0.000 \\
\hline 782.2 & 0.075 & 0.000 & 0.000 & 0.000 \\
\hline 782.1 & 0.000 & 0.000 & 0.000 & 0.000 \\
\hline
\end{tabular}
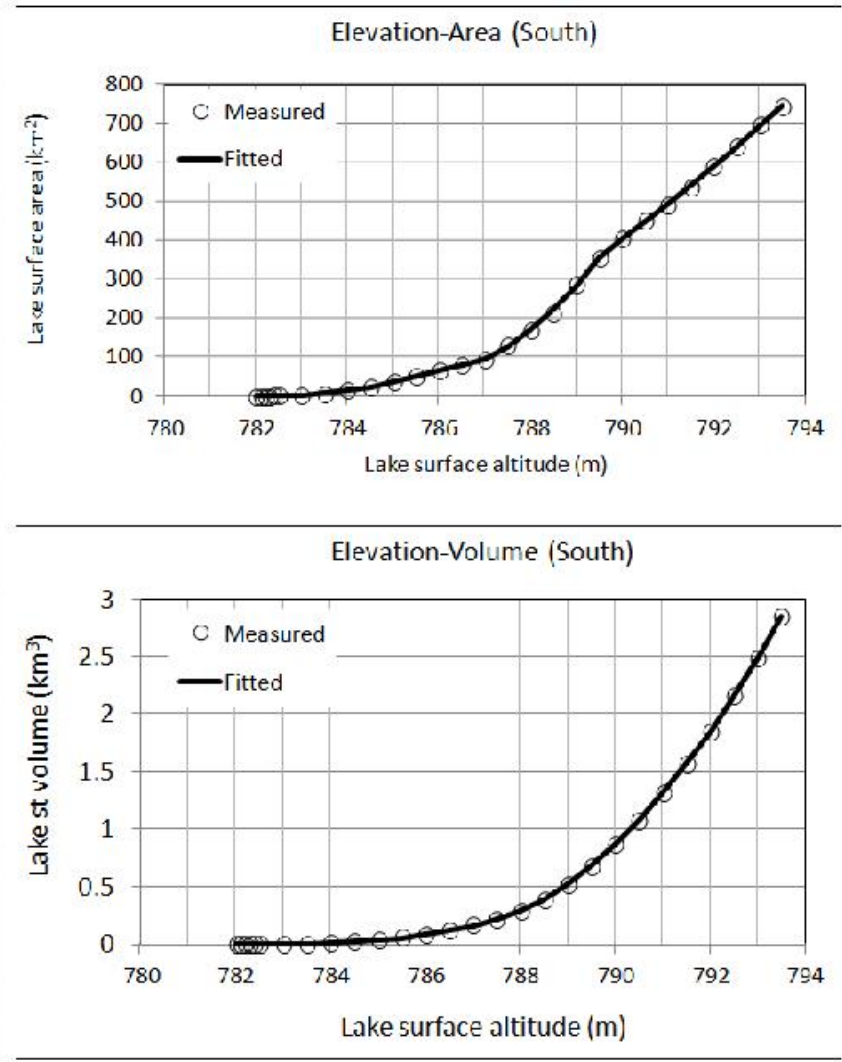

Figure 7: Elevation-area-volume data and equations for south basin of Lake Rukwa. 
Table 2: Differences between lake surface areas and volumes for various historical extents.

\begin{tabular}{|c|c|c|c|c|c|c|}
\hline \multirow[b]{2}{*}{ Alt (m) } & \multicolumn{3}{|c|}{ Volume $\left(\mathbf{k m}^{\mathbf{3}}\right)$} & \multicolumn{3}{|c|}{ Area $\left(\mathbf{k m}^{2}\right)$} \\
\hline & Refined & Old & Difference $(\%)$ & Refined & Old & Difference $(\%)$ \\
\hline 787 & 0.163 & 0.004 & 4316.3 & 94.44 & 10.8 & 774.1 \\
\hline 792 & 3.569 & 1.051 & 239.4 & $1,838.18$ & 971.9 & 89.1 \\
\hline 794.3 & 10.055 & 5.896 & 70.5 & $3,391.50$ & $2,931.0$ & 15.7 \\
\hline 795 & 12.165 & 8.140 & 49.4 & $3,596.65$ & $3,311.3$ & 8.6 \\
\hline 796 & 15.984 & 11.739 & 36.2 & $3,917.07$ & $3,791.6$ & 3.3 \\
\hline 796.3 & 17.183 & 12.9005 & 33.2 & $4,003.47$ & $3,924.7$ & 2.0 \\
\hline 796.8 & 19.232 & 14.9165 & 28.9 & $4,139.55$ & $4,137.5$ & 0.0 \\
\hline 797 & 20.069 & 15.750 & 27.4 & $4,191.51$ & $4,219.8$ & -0.7 \\
\hline 798 & 24.392 & 20.135 & 21.1 & $4,433.56$ & $4,610.1$ & -3.8 \\
\hline 799 & 28.932 & 24.865 & 16.4 & $4,651.33$ & $4,971.1$ & -6.4 \\
\hline 800 & 33.674 & 29.916 & 12.6 & $4,850.12$ & $5,308.7$ & -8.6 \\
\hline 800.8 & 37.603 & 34.174 & 10.0 & $4,997.97$ & $5,564.7$ & -10.2 \\
\hline 801 & 38.603 & 35.2677 & 9.5 & $5,033.57$ & 5636.8 & -10.7 \\
\hline 802 & 43.708 & 40.9052 & 6.9 & $5,204.33$ & 5636.9 & -7.7 \\
\hline 803 & 48.980 & 46.8141 & 4.6 & $5,364.39$ & 5637.1 & -4.8 \\
\hline 804.69 & 58.243 & 57.384 & 1.5 & $5,614.68$ & $5,637.3$ & -0.4 \\
\hline 804.85 & 59.142 & 58.4218 & 1.2 & $5,637.23$ & 5637.3 & 0.0 \\
\hline 805 & 59.989 & 59.3999 & 1.0 & $5,658.20$ & 5637.3 & 0.4 \\
\hline 807 & 71.573 & 72.9449 & -1.9 & $5,923.84$ & 5637.6 & 5.1 \\
\hline 808 & 77.566 & 80.0566 & -3.1 & $6,048.03$ & 5637.7 & 7.3 \\
\hline
\end{tabular}

\section{CONCLUSIONS}

Contours generated from a refined bathymetry of Lake Rukwa constructed from a combination of sounded bathymetric points, spot heights in topographical maps, digitised lake shorelines from old maps and digitised land contour indicated Lake Rukwa to comprise two north and south lake basins, which are separated by a ridge lying at an altitude of $794.3 \mathrm{~m}$. The north and south lakes consist respectively of five (5) and three (3) deeper depressions (pools) paralleling the northwest-southeast Konongo Scarp with deepest sounded points at 784.36 and $778.37 \mathrm{~m}$ for north and south lakes respectively. These pools are disconnected below altitudes $792 \mathrm{~m}$ (north) and $789.4 \mathrm{~m}$ (south).
Characteristic elevation-area and elevationvolume equations are segmented for lake below ridge altitude whereas single relationships prevail for a single lake. Comparison of lake volumes estimated by refined and old equations indicated underestimation of lake stored volumes between $782.2 \mathrm{~m}$ and $805.65 \mathrm{~m}$ altitudes and overestimation thereafter by the old equations although the under/overestimation remained within $10 \%$ between 801 $\mathrm{m}$ and $812 \mathrm{~m}$. Old elevation-area equations underestimate lake surface area up to $796.8 \mathrm{~m}$, thereafter overestimates the lake area up to an altitude of $804.85 \mathrm{~m}$ and above this altitude underestimation re-appears. The old equations under/over-estimation, but remains within $11 \%$ for altitudes between $794.3 \mathrm{~m}$ and $810 \mathrm{~m}$.

The refined equations indicate surface areas of north and south lakes at ridge altitude to be 
2,554.4 $\mathrm{km}^{2}$ and $837.1 \mathrm{~km}^{2}$, respectively forming a $3,391.5 \mathrm{~km}^{2}$ lake. At its highest recorded historical elevation of $804.69 \mathrm{~m}$, Lake Rukwa is $183 \mathrm{~km}$ long and 17-51 km wide occupying an area of $5,614.7 \mathrm{~km}^{2}$ (north: 4,409.8 $\mathrm{km}^{2}$; south: 1,204.9 $\mathrm{km}^{2}$ ) and containing $58.243 \mathrm{~km}^{3}$ of water (north: 44.318 $\mathrm{km}^{3}$; south: $13.925 \mathrm{~km}^{3}$ ). At its recent March 2014 water surface altitude $(\sim 800.8 \mathrm{~m})$, the lake was $177 \mathrm{~km}$ long and 16-49 km wide with a surface area of $4,997.7 \mathrm{~km}^{2}$ (north: $3,918.3$ $\mathrm{km}^{2}$; south: $1,079.4 \mathrm{~km}^{2}$ ) containing 37.603 $\mathrm{km}^{3}$ of water (north: $28.055 \mathrm{~km}^{3}$; south: 9.548 $\mathrm{km}^{3}$ ). Whilst elevation-area and elevationvolume equations for the lake have been improved in this study, these characteristic equations for separated north and south lake basins are given for the first time. Although few additional bathymetric points are recommended for collection at strategic unsurveyed locations including pools in north lake basin for improving further the lake bathymetry, the developed characteristic equations can be used for water management studies of Lake Rukwa.

\section{ACKNOWLEDGEMENTS}

iWASH programme is highly acknowledged for funding the bathymetry survey of Lake Rukwa and Lake Rukwa Basin Water Board (LRBWB) for availing bathymetry data for this study.

\section{REFERENCES}

Baker N.E. and Baker E.M. (2002). Important bird areas in Tanzania. Wildlife Conservation Society of Tanzania. Dar es Salaam, Tanzania.

Britannica (2016). Lake Rukwa, Tanzania. Available online at www.britannica.com/place/Lake-Rukwa. Accessed on $24^{\text {th }}$ February 2016.

Gunn D.L. (1956). History of Lake Rukwa and the Red Locust, Tanganyika Notes and Records, 42(1): 1 - 18.
Hyams D.G. (2011). CurveExpert Professional documentation. Release 1.5.0, 162p.

IRD-HSM (2013). Khronostat, logiciel statistique de series chronologiques. Copyright Orstom 1998-IRD 2002, Montpellier, France, 2002.

Lakepedia (2016). Lake Rukwa, Tanzania. Available online at www.lakepedia.com/lake/rukwa. Accessed on $24^{\text {th }}$ February 2016.

LEGOS/GEOS (2015). Surface monitoring by satellite altimetry: Lake Rukwa. Available online at www.legos.obsmip.fr/soa/hydrologie/hydroweb/StationsVir tuelles/SV_Lakes/Rukwa.html. Accessed on $15^{\text {th }}$ January 2016.

LRBWB-MoW (2014). Lake Rukwa bathymetry report, Lake Rukwa Basin Water Board, Ministry of Water and Irrigation, Dar es Salaam, Tanzania, 54p.

Nicholson S.E. (1999). Historical and modern fluctuations of Lakes Tanganyika and Rukwa, Climatic Change, 41: 53 - 71.

Ritcher B.D., Baumgartner J.V., Braun D.P. and Powell J. (1998). A spatial assessment of hydrological alteration within a river network, Regul. Rivers: Res. Mgmt, 14: 329-340.

URT-MoW (2017). Environmental Water Requirements Assessment Guidelines for Tanzania, Final Draft. Ministry of Water and Irrigation, 144p.

Valimba P. (2015). Water balance study of Lake Rukwa. United Republic of Tanzania/Ministry of Water/Lake Rukwa Basin Water Board, 166p.

Wikipedia (2016). Lake Rukwa. Available online at https//en.m.wikipedia.org/wiki/Lake_Rukwa . Accessed on $24^{\text {th }}$ February 2016.

World Lakes (2016). Lake profile Rukwa. Available online at www.worldlakes.org/lakedetails.asp?lakeid $=8579$. Accessed on $24^{\text {th }}$ February 2016 . 